\title{
RESPONSE OF YOUNG 'TAHITI' LIME TREES TO DIFFERENT IRRIGATION LEVELS
}

\author{
JOSÉ ALVES JÚNIOR ${ }^{1}$, MARCOS V. FOLEGATTI ${ }^{2}$, CLÁUDIO R. DA SILVA ${ }^{3}$, \\ TONNY J. A. DA SILVA ${ }^{4}$, ADÃO W. P. EVANGELISTA ${ }^{5}$
}

\begin{abstract}
The aim of this study was to evaluate the effect of different irrigation levels on canopy and root growth, productivity, and fruit quality of young 'Tahiti' acid lime trees. The experiment was installed in Piracicaba, Brazil in a 1.0-ha orchard plot with 'Tahiti' acid lime trees, grafted on 'Swingle' citrumelo rootstock and carried out from August of 2002 to May 2005. Each treatment was assigned to a drip irrigation level, based on ETc as follows: T1) non-irrigated, T2) 25\%, T3) $50 \%$, T4) $75 \%$ and T5) $100 \%$ of ETc determined by weighing lysimeter presented in the orchard plot. Trunk diameter and tree height were evaluated monthly. The roots were evaluated when the trees were 30 and 48 months old. The yield and fruit quality was evaluated in 2004 and 2005. The results showed that irrigation did not influence root distribution in depth, and trees irrigated with $75 \%$ and $100 \%$ ETc showed horizontal root distribution concentrated until $0.6 \mathrm{~m}$ from the trunk. Irrigation did not improve the quality of fruit. Yield increased in all irrigated treatment, but the most efficient yield mean per unit of water applied was the $25 \%$ ETc treatment.
\end{abstract}

KEYWORDS: irrigation scheduling, Citrus latifolia Tan., evapotranspiration, root distribution.

\section{RESPOSTA DE PLANTAS JOVENS DE LIMEIRA-ÁCIDA 'TAHITI’ A DIFERENTES NÍVEIS DE IRRIGAÇÃO}

RESUMO: O objetivo deste trabalho foi avaliar o efeito de diferentes níveis de irrigação sobre o crescimento da copa e raízes, produtividade e qualidade de frutos de plantas jovens de limeira-ácida 'Tahiti'. O experimento foi instalado em Piracicaba, em um hectare plantado com limeira-ácida 'Tahiti' enxertadas sobre porta-enxerto citromelo 'Swingle'e irrigadas por gotejamento. O experimento foi conduzido durante o período de agosto de 2002 a maio de 2005. Cada tratamento correspondeu a um nível de irrigação baseado nos valores de evapotranspiração da cultura (ETc): T1) não irrigado; T2) 25\%; T3) 50\%; T4) $75 \%$ e T5) $100 \%$ da ETc determinada por meio de um lisímetro de pesagem, presente na área. $\mathrm{O}$ diâmetro e a altura das plantas foram avaliados mensalmente. As raízes foram avaliadas quando as plantas estavam com 30 e 48 meses de idade. A produtividade e a qualidade dos frutos foram avaliadas em 2004 e 2005 . Os resultados mostraram que a irrigação não influenciou na distribuição do sistema radicular em profundidade, e que plantas irrigadas com lâminas de água equivalentes a 75 e $100 \%$ da ETc mostraram uma distribuição horizontal de raízes concentradas a $0,60 \mathrm{~m}$ de distância do tronco. Aos 48 meses, a irrigação não influenciou na distribuição do sistema radicular no perfil do solo. A irrigação não melhorou a qualidade dos frutos. A produtividade aumentou em todos os tratamentos irrigados, mas o tratamento correspondente à lâmina de $25 \%$ da ETc foi o mais eficiente por unidade de água aplicada.

PALAVRAS-CHAVE: manejo de irrigação, evapotranspiração, Citrus latifolia, raiz.

\footnotetext{
${ }^{1}$ Universidade Federal de Goiás, Escola de Agronomia e Engenharia de Alimentos, Câmpus Samambaia, Goiânia - GO, Brasil, jose.junior@pesquisador.cnpq.br.

2 Universidade de São Paulo, Departamento de Engenharia de Biossistemas, Escola Superior de Agricultura "Luiz de Queiroz" ESALQ/USP, Piracicaba - SP, Brasil, mvfolega@eslq.usp.br.

${ }^{3}$ Universidade Federal de Uberlândia-UFU, Instituto de Ciências Agrárias, Campus Umuarama, Uberlândia, Brasil, claudio@iciag.ufu.br.

${ }^{4}$ Universidade Federal de Mato Grosso - UFMT, Campus de Rondonópolis, Rondonópolis, Brasil, tonny.silva@pq.cnpq.br.

${ }^{5}$ Universidade Federal de Goiás. Escola de Agronomia e Engenharia de Alimentos, Campus Samambaia, Goiânia, GO, Brasil. awpego@bol.com.br
}

Recebido pelo Conselho Editorial em: 25-5-2009

Aprovado pelo Conselho Editorial em: 21-2-2011 


\section{INTRODUCTION}

'Tahiti' acid lime [Citrus latifolia (Yu. Tanaka) Tanaka] starts to produce an economical yield when trees are 3 years old and contribute substantially to the citrus income (AGRIANUAL, 2007). This species can adapt to different soil types. In the State of São Paulo, acid limes can thrive anywhere, except in areas where temperatures are extreme.

A few years ago, the State of São Paulo was considered the only region in the world with the highest production of citrus under no irrigation. Although the State of São Paulo receives annual rainfall in the range 1,200 to $1,600 \mathrm{~mm}$, about $80 \%$ of the rainfall occurs from October to April, and does not coincide with the critical flowering and fruit set stage of the crop. BUSTAN \& GOLDSCHMIDT (1998) related that in the reproductive period, 70\% of the carbon assimilated by the plant is used to produce flowers and fruits. Studies showed that inadequate rainfall during these periods can significantly reduce yields. Because of the above reasons, the irrigated area in São Paulo under citrus is increasing. Currently, about $15 \%$ of the 651 thousand hectares cultivated in São Paulo (USDA, 2005) receive irrigation (PARSONS, 2005).

During the first several years after planting, there is generally a good relationship between increased irrigation and increase in canopy volume and yield (PARSONS et al., 2001). However, as trees reach full size, excessive growth induced by over-irrigation and fertilization can decrease yields because of shading and the need for hedging large amounts of vegetative and reproductive material (WHEATON et al., 1991). Water shortages typically increase concentration of Brix in the juice, while excessive rainfall or irrigation results in dilution of the sugars or total soluble solids in the juice (DAVIES \& ALBRIGO, 1994).

Because of their year-round growth and production, lime trees demand about $10 \%$ to $20 \%$ more irrigation than oranges and trees planted in grass should receive about $20 \%$ more water than trees with no grass or ground cover (WRIGHT, 2000).

In addition, many new orchards are using rootstocks that are less tolerant of water stress. These rootstocks are used to control Citrus Sudden Death occurrence in the Northern region of São Paulo, where water shortages are severe.

Despite of benefits of citrus irrigation, the shortage of water and the unavailability of required information for efficient irrigation scheduling is a problem that producers face. Excessive use of irrigation water is wasteful, as it may result in poor fruit quality, leaching of nutrients and increased risk of root rots. Irrigation techniques that guarantee maximum efficiency of water use should be used (BOLLER et al., 2004). Increasing the efficiency of irrigation by reducing water wastage is an important way to save water without affecting productivity. This saved water can be used to expand the area under irrigation.

Information about irrigation of citrus, which was developed in other regions, or with different combinations of rootstock and scion varieties, and different soils and irrigation systems, could be not adequate for São Paulo conditions. Therefore, the objective of this study is to evaluate the effect of irrigation levels ( $0 \%$ to $100 \%$ of crop evapotranspiration measured by weighing lysimeter) on 'Tahiti' acid lime young tree canopy and root growth, productivity, and quality of fruit, under drip irrigation in the field.

\section{MATERIAL AND METHODS}

The experiment was conducted during a 3-year period (Aug. 2002 to May 2005, totalizing 34 months) in a 1.0-ha plot planted with 'Tahiti' acid lime trees (Citrus latifolia Tanaka), grafted on 'Swingle' [Poncirus trifoliata (L.) Raf. $\times$ Citrus paradisi Macf.] citrumelo rootstock. The trees were 1 year old and spaced $7 \times 4 \mathrm{~m}$, and were drip-irrigated using 4 pressure compensated drippers of $4 \mathrm{~L} \mathrm{~h}^{-1}$ (uniformity of 95\%) per each tree. The closest dripper was $0.5 \mathrm{~m}$ from the trunk, and drippers formed 2 wet bulbs in each side of the tree. The orchard was located in Piracicaba, State of

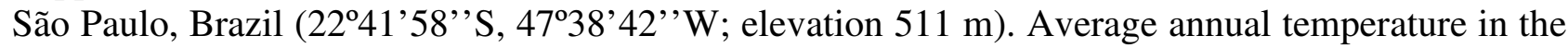


area was $21.4^{\circ} \mathrm{C}$ and annual rainfall was $1,257 \mathrm{~mm}$. The soil was a Rhodic Kandiudalf, clay texture, $5 \%$ average slope. Plant available soil water was $0.125 \mathrm{~m}^{3} \mathrm{~m}^{-3}$. The average bulk density of the soil measured between $0.2 \mathrm{~m}$ and $1 \mathrm{~m}$ depth was $1.3 \mathrm{Mg} \mathrm{m}^{-3}$. The orchard floor was kept free of weeds during the experimental period. Ordinary pest control practices were performed and the fertilization was done as recommend by van RAIJ et al. (2000).

In the experimental plot, 50 trees which were identical in size were selected and divided into 5 groups. Each group was assigned to a different irrigation, treatments based on crop evapotranspiration (ETc) as follows: T1) non-irrigated, T2) $25 \%$, T3) 50\%, T4) $75 \%$, and T5) $100 \%$ of ETc as determined by a weighting lysimeter.

The weighting lysimeter (2.7-m diameter x $0.8-\mathrm{m}$ depth) was set up in the center of the experimental area with one tree in it. Details about the lysimeter construction and calibration can be obtained in BARBOSA Jr. et al. (2008). The precision of the weight measurements were about $0.268 \mathrm{~kg}(0.0468 \mathrm{~mm})$. Daily crop evapotranspiration $(E T c)$ was calculated from daily weight changes in the lysimeter. The tree in the lysimeter was irrigated and managed like the rest of the trees in the experimental area. The meteorological data (Fig.1C and 3) for the years during the period was collected by an automatic weather station (CR 23X, Campbell Scientific, Logan, USA) located about $70 \mathrm{~m}$ away from the orchard.

The frequency of irrigation was of 2 in 2 days by drip irrigation system (Tab. 3). The irrigation level was adjusted using a different number of dripper emitters per tree. In T2 (25\% ETc) one dripper was used, T3 (50\% ETc) two drippers, T4 (75\% ETc) three drippers, and T5 (100\% $E T c$ ) four drippers. The drippers in T2, T3, and T4 were adapted with dividers of flow and microtub (Way Multi - Outlet Dripper) to irrigate all treatments with 4 wet bulbs. Where T2 $(25 \%$ ETc) was irrigated with 4 wet bulbs of $1 \mathrm{Lh}^{-1}$, T3 (50\% ETc) with 4 wet bulbs of $2 \mathrm{Lh}^{-1}$, T4 (75\% ETc) with 2 wet bulbs of $2 \mathrm{Lh}^{-1}$ and 2 wet bulbs of $4 \mathrm{Lh}^{-1}$, and T5 (100\% ETc) with 4 wet bulbs of $4 \mathrm{Lh}^{-1}$, totalizing $4,8,12$, and $16 \mathrm{Lh}^{-1}$ tree ${ }^{-1}$, in T2, T3, T4, and T5, respectively. The experimental was a completely randomized design, with 5 treatments (irrigation levels) and 10 replications (one tree each).

The tree growth was evaluated in all 50 trees monthly during the period from August 2002 to April 2005. The trunk diameter was measured $0.05 \mathrm{~m}$ above the graft line, and the tree height was measured from the soil surface to the average height of the tallest branches (ALVES JR. et al., 2005).

The roots under irrigation levels were evaluated when the trees were 30-months-old, and again when the trees were 48-months-old, using the method explained by BÖHM (1979). Two trees were used by each treatment (irrigation levels with $0 \%, 25 \%, 50 \%, 75 \%$, and $100 \%$ of ETc). First sampling was made at 4 horizontal distances from tree trunk $(0.3,0.6,0.9$, and $1.2 \mathrm{~m})$ and 2 depths ( 0.0 to 0.3 and 0.3 to $0.6 \mathrm{~m}$ ). For the second, it was made at 5 horizontal distances from the trunk $(0.3,0.6,0.9,1.2$, and $1.5 \mathrm{~m})$, and 3 depths ( 0.0 to $0.3,0.3$ to 0.6 , and 0.6 to $0.9 \mathrm{~m})$.

Soil cores were collected using a soil auger with a diameter of $0.09 \mathrm{~m}$ and height of $0.25 \mathrm{~m}$. Roots were separated from the soil using screens ( $2 \mathrm{~mm}$ opening). Roots were then dried at $65{ }^{\circ} \mathrm{C}$ for $72 \mathrm{~h}$ and weighed. Feeder roots were identified considering them as, all roots with a diameter less than $1.5 \mathrm{~mm}$.

The yield was evaluated by measuring the weight and number of fruits per tree in 2004 and 2005. Harvests were done 4 times during 2004 (February, March, May and August) and 3 times in 2005 (February, May and August), at 18, 19, 21, 24, 32 and 38 months after the experiment had started. All fruit were harvested manually on the basis of coloration of the rind. The fruits were harvested using the Brazilian classification system (HORTBRASIL, 2000). The two rind color intensities used were C3 and C4. From the harvest, a subsample of 10 fruits per replication was randomly selected for quality analysis. The fruits were washed and placed in plastic bags and stored at $10{ }^{\circ} \mathrm{C}$ for $12 \mathrm{~h}$. The measurement criteria for fruit diameter (equatorial), rind thickness, and 
percent of juice were as described by ALVES JR. (2006). From the extracted juice, the total soluble solids $\left({ }^{\mathrm{O}} \mathrm{Brix}\right.$ ) was measured using a portable refractometer (resolution 0.2 ), $\mathrm{pH}$ using potentiometer (resolution 0.01), and total acidity (\%) using titration method as describe by AOAC (1970) cited by ALVES JR. et al. (2006).

\section{RESULTS AND DISCUSSION}

\section{The growth of lime trees}

In the first nine months, the growth rate of the height tree was very similar in all treatments (Fig.1A). This time coincided with the wet season where the radiation and air temperature were high (Fig. 1C). As there was no water stress during this period, treatments showed similar growth rates for tree height as trunk diameter (Fig. $1 \mathrm{~B}$ and $1 \mathrm{~B}_{1}$ ). Therefore, during this time, the treatments did not show significant differences, although the tree height in $100 \%$ ETc (T5) compared to the treatments non irrigated (T1) showed higher values at the third month of the experiment, T5 tree height was not significantly greater than T1 until the 12 month (Sept. 2003). Tree height in T5 was about 17\% greater than T1 (Fig. 1A and 1A 1 ). During the 12 to 18 month (July 2003 to Jan. 2004) these differences were more pronounced, and it could be observed a more intense growth in the treatments irrigated at $75 \%$ and $100 \%$ of ETc as compared to less irrigated ( 25 and $50 \%$ of ETc). This time corresponded to a great decrease in pluvial precipitation (Fig 1C and Fig. 3) and then soil water deficit. After 18 month, there was a stabilization of rate of growth in all treatments, however, with lower rate at $\mathrm{T} 1$ (non-irrigated trees).

For trunk diameter (Fig. $1 \mathrm{~B}$ and $1 \mathrm{~B}_{1}$ ), the results were similar to trees height but with differences less pronounced, except by the end of the experiment. The results suggested that the water deficits that occurred during July to January of 2004 (Fig. 3) caused a low rate of growth in tree height and trunk diameter. Studies have showed that young citrus tree growth is strongly affected by water deficit especially during the first years after planting (ALVES JR. et al., 2005). CASTEL (1993) found a linear relation between the trunk diameter and the irrigation level. CASTEL (1994) also observed that young 'Clementine de Nunes' mandarin trees irrigated at 50\% ETc showed water stress and lower growth when compared with trees irrigated at $100 \%$ of ETc. However, GINESTAR \& CASTEL (1996) observed reduction on perimeter trunk with water stress but not in a clear way. 

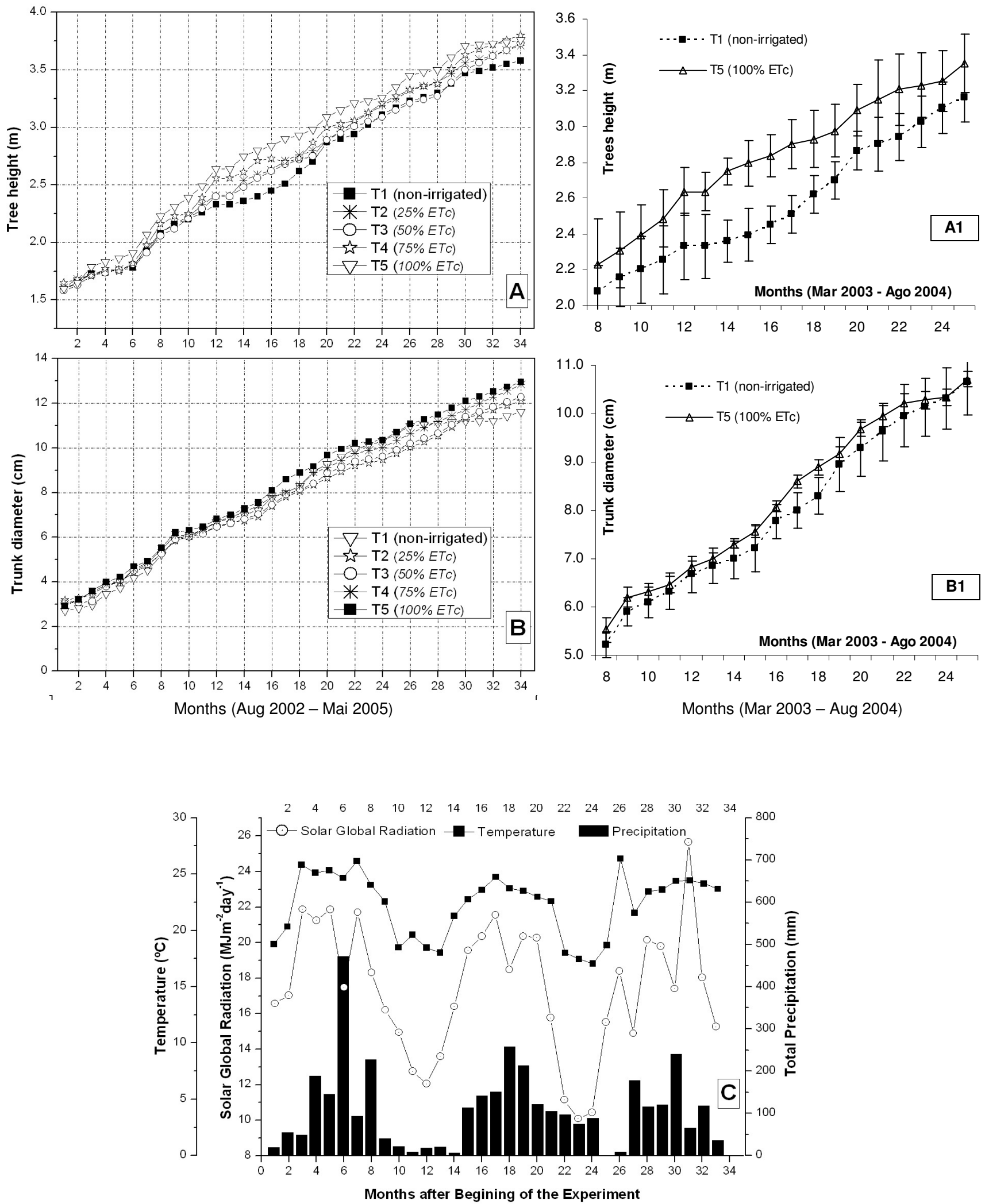

FIGURE 1. Monthly measurement of tree height (A), trunk tree diameter (B) and climatic data throughout the experiment (C). Piracicaba, Brazil. Legend: T1) non-irrigated, T2) $25 \%$, T3) $50 \%$, T4) $75 \%$ and T5) $100 \%$ of crop evapotranspiration.

\section{Root distribution of lime trees}

The results (Tab.1 and Fig.2) from first sampling (after 16 months of the experiment beginning) showed that there was a significant difference in root distribution (in depth and horizontally). About $51.0 \mathrm{~kg} \mathrm{~m}^{-3}(69 \%)$ of root density was concentrated between 0.0 to $0.6 \mathrm{~m}$ from 
the trunk and about $56.2 \mathrm{~kg} \mathrm{~m}^{-3}(78 \%)$ of the total roots were found between 0.0 to $0.3 \mathrm{~m}$ depth. Similar results were obtained in the second sampling but with a light growth in both horizontal as depth. These results agree with COELHO et al. (2002), MORGAN et al. (2006) and TESTEZLAF et al (2007) which observed that roots of citrus trees normally are concentrated horizontally between 0.5 and $2 \mathrm{~m}$ from the stem of the tree and between 0 and $1 \mathrm{~m}$ of depth. MATTOS JR. et al. (2003) found also, that roots were concentrated horizontally at a distance of $0.5 \mathrm{~m}$ from the trunk in mature 'Hamlin' orange on 'Swingle' citrumelo rootstock trees (6 years old).

There was more root and feeder root density at high levels of irrigation (T4 and T5) in horizontal root distribution in the first sampling. This was probably due to the wider wetting area (about 0.5 to $0.6 \mathrm{~m}$ wet bulb diameter) promoted by drippers of $4 \mathrm{Lh}^{-1}$ in T4 and T5. It showed that there is a trend for roots to be concentrated in the wetted area, due to the higher rate of water application by the irrigation. The results from the second sampling (after 34 months of beginning of experiment in trees with 48 months old) showed that there was no significant difference between irrigation levels and root distribution pattern $(P<0.05)$.

TABLE 1. Analysis of variance and ' $F$ ' test of total root distribution of young tree of acid lime 'Tahiti' with 'Swingle' citrumelo, irrigated under different irrigation levels in Piracicaba, Brazil.

\begin{tabular}{lcccc}
\hline \multirow{2}{*}{ Variation } & \multicolumn{2}{c}{ Roots at 30 months } & \multicolumn{2}{c}{ Roots at 48 months } \\
\cline { 2 - 5 } & \multicolumn{3}{c}{ Characteristics } \\
\cline { 2 - 5 } Depth (D) & D.F. & $66.06^{* *}$ & D.F. & F \\
Horizontal distance (H) & 1 & $17.94^{* *}$ & 4 & $43.41^{* *}$ \\
Irrigation levels x D & 3 & $4.00 \mathrm{~ns}$ & 8 & $34.13^{* *}$ \\
Irrigation levels x H & 4 & $2.99^{* *}$ & 16 & $1.08 \mathrm{~ns}$ \\
C.V. $(\%)$ & 12 & 51.2 & & $54.07 \mathrm{~ns}$ \\
\hline
\end{tabular}

** - significant at 5\% (P>0.05); ns - non significance by 'F' Test; D.F. - degrees of freedom; C.V. - variation coefficient.
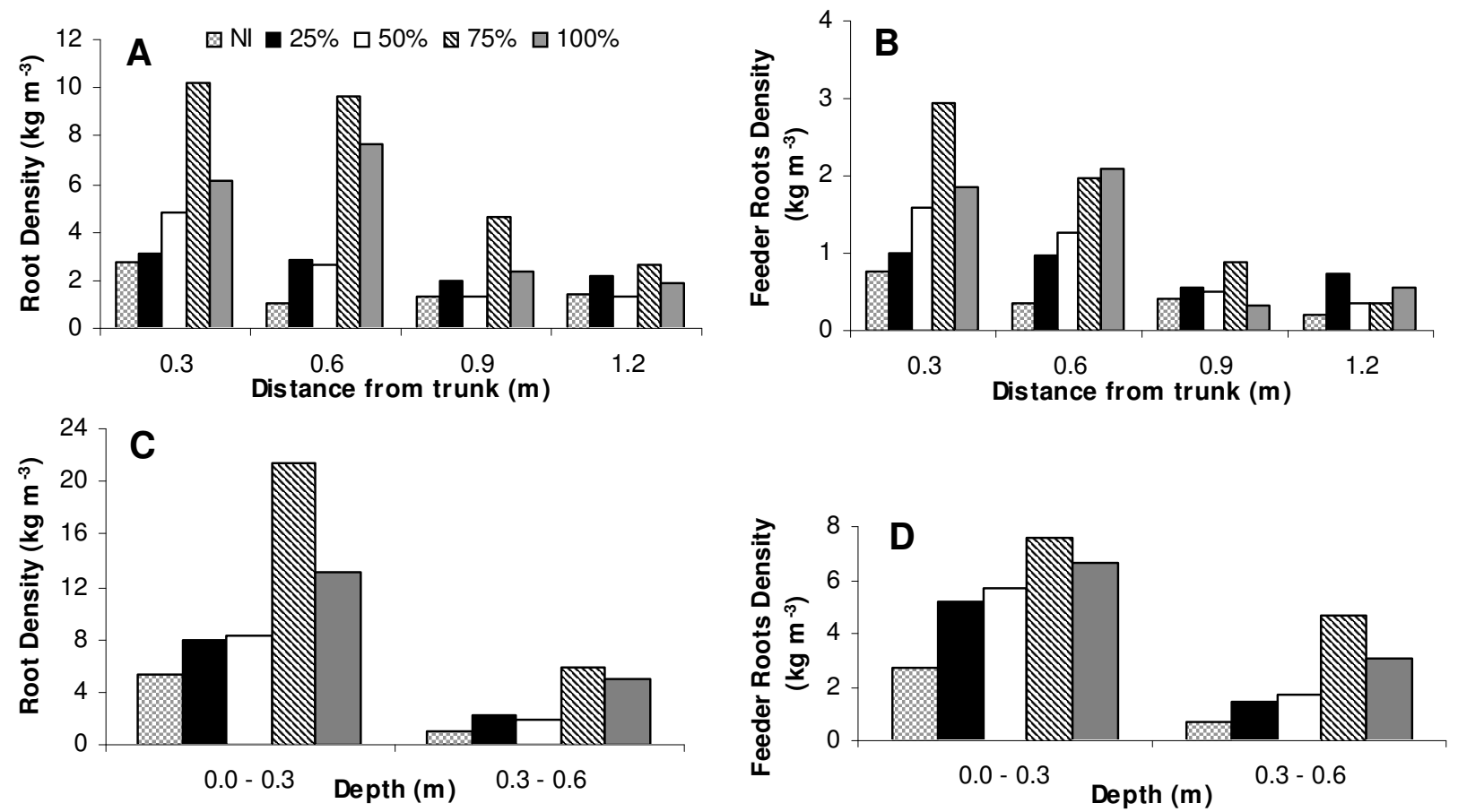

FIGURE 2. Horizontal (A and B) and depth distribution (C and D) of roots and feeder roots at 16 months of beginning of experiment in the treatments of trees with 30 months old, Piracicaba, Brazil. 
The root distribution values are in accordance with results reported in literature. SANTOS et al. (2005) verified that the lemon roots grow more with increase in the irrigation intervals and lemon roots extract more water when there is no restriction to the available water in the wetted volume.

CASTLE et al. (1993), who studied root distribution in different rootstocks and observed about $90 \%$ of roots within $0.6 \mathrm{~m}$ of depth and horizontal distance of $2 \mathrm{~m}$, and about $85 \%$ of these roots were feeder roots. SOUZA et al. (2004) and SANTANA et al. (2006) studied citrus roots distribution of 'Bahia' orange (Citrus sinensis (L.) Osbeck) grafted onto Rangpur lime in a coastal plain soil toposequence in Sapeaçu country, Bahia, Brazil, in soil compact level between 0.3 and $0.5 \mathrm{~m}$, observed about $61 \%$ of roots within $0.2 \mathrm{~m}$ and $90 \%$ within $0.4 \mathrm{~m}$. Some results are different than that observed in our study, probably due these studies evaluated different species, rootstock, age, and grove management, and this may explain the difference.

\section{Yield and quality of lime fruits}

The first year the results (Table 2) showed that yields among the different treatments were significant $(P<0.05)$. The yield in T2 $(25 \%$ ETc $)$, T4 $(75 \%)$, and T5 $(100 \%$ ETc) was greater than T1 (no irrigation). The yield in T3 (50\% of ETc) was intermediate. Although T5 $\left(53 \mathrm{~kg} \mathrm{tree}^{-1}\right)$ did not differ significantly from T2 (44 kg tree $\left.{ }^{-1}\right)$, T3 $\left(39 \mathrm{~kg}\right.$ tree $\left.{ }^{-1}\right)$, and T4 $\left(45 \mathrm{~kg}\right.$ tree $\left.{ }^{-1}\right)$, it was $22 \%$ higher. T4 was not significantly different from T3, but its yield was $15 \%$ higher. T3 received double the amount of water of T2 (Table 3), it showed a 15\% lower yield and T3 did not differ significantly from $\mathrm{T} 1\left(24 \mathrm{~kg}\right.$ tree $\left.^{-1}\right)$ but its yield was $62 \%$ higher. In all these treatments, the yield reduction was due mostly to fewer fruit as the final fruit size was not significantly affected.

TABLE 2. Yield parameters and fruit quality of 'Tahiti' lime under irrigation levels (T1, nonirrigated; T2, 25\%; T3, 50\%; T4, 75\% and T5, 100\% of crop evapotranspiration). Analyses of 2004 and 2005. Piracicaba, Brazil.

\begin{tabular}{|c|c|c|c|c|c|c|c|c|}
\hline \multicolumn{9}{|c|}{ First year (2004) } \\
\hline Treatments & $\begin{array}{c}\text { Yield } \\
\mathrm{kg}_{\text {tree }}^{-1}\end{array}$ & $\begin{array}{c}\text { Fruits } \\
\mathrm{n}^{\circ} \cdot \text { tree }^{-1}\end{array}$ & $\begin{array}{c}\text { Juice } \\
\%\end{array}$ & $\begin{array}{c}\text { Fruit } \\
\text { Diameter } \\
\text { Mm }\end{array}$ & $\begin{array}{c}\text { Rind } \\
\text { Thickness } \\
\text { mm }\end{array}$ & $\begin{array}{c}\text { Acidity } \\
\%\end{array}$ & $\mathrm{pH}$ & $\begin{array}{c}\text { Soluble } \\
\text { Solids } \\
{ }^{\circ} \text { Brix }\end{array}$ \\
\hline $\mathrm{T} 1$ & $24.1 b$ & $332 b$ & $41.9 a$ & $50.4 a$ & $2.7 \mathrm{a}$ & $6.6 a$ & $2.6 a$ & $8.0 \mathrm{a}$ \\
\hline $\mathrm{T} 2$ & $44.9 \mathrm{a}$ & $644 \mathrm{a}$ & $43.3 \mathrm{a}$ & $50.6 \mathrm{a}$ & $2.7 \mathrm{a}$ & $7.0 \mathrm{a}$ & $2.5 \mathrm{a}$ & $8.0 \mathrm{a}$ \\
\hline $\mathrm{T} 3$ & $39.0 \mathrm{ab}$ & $611 \mathrm{a}$ & $44.8 \mathrm{a}$ & $50.0 \mathrm{a}$ & $2.7 \mathrm{a}$ & $7.6 \mathrm{a}$ & $2.5 \mathrm{a}$ & $8.2 \mathrm{a}$ \\
\hline $\mathrm{T} 4$ & $45.2 \mathrm{a}$ & $665 a$ & $39.1 \mathrm{a}$ & $50.9 \mathrm{a}$ & $2.7 \mathrm{a}$ & $7.3 \mathrm{a}$ & $2.6 \mathrm{a}$ & 7.9a \\
\hline T5 & $53.6 \mathrm{a}$ & $761 \mathrm{a}$ & $39.3 \mathrm{a}$ & $51.3 \mathrm{a}$ & $2.7 \mathrm{a}$ & $7.4 \mathrm{a}$ & $2.5 \mathrm{a}$ & 7.9a \\
\hline Average & 41.4 & 603 & 41.7 & 50.6 & 2.7 & 7.30 & 2.5 & 8.0 \\
\hline LSD & 16.2 & 217.9 & 18.1 & 1.9 & 0.29 & 1.50 & 0.14 & 0.44 \\
\hline C.V. & 31.8 & 29.8 & 16.1 & 1.4 & 8.97 & 12.4 & 2.08 & 2.11 \\
\hline \multicolumn{9}{|c|}{ Second year (2005) } \\
\hline T1 & $28.4 \mathrm{~b}$ & $373 a$ & $56.4 \mathrm{a}$ & $50.4 \mathrm{a}$ & $2.7 \mathrm{a}$ & $6.5 \mathrm{a}$ & $2.0 \mathrm{a}$ & $7.6 \mathrm{a}$ \\
\hline $\mathrm{T} 2$ & $40.0 \mathrm{a}$ & $484 a$ & $57.6 a$ & $50.4 a$ & $2.8 \mathrm{a}$ & $6.4 \mathrm{a}$ & $2.0 \mathrm{a}$ & $7.4 \mathrm{a}$ \\
\hline T3 & $35.9 \mathrm{ab}$ & $477 \mathrm{a}$ & $53.4 \mathrm{a}$ & $50.3 \mathrm{a}$ & $2.8 \mathrm{a}$ & $6.4 \mathrm{a}$ & $2.0 \mathrm{a}$ & $7.6 \mathrm{a}$ \\
\hline $\mathrm{T} 4$ & $37.1 \mathrm{a}$ & $456 a$ & $56.8 \mathrm{a}$ & $50.3 \mathrm{a}$ & $2.9 a$ & $6.4 \mathrm{a}$ & $2.0 \mathrm{a}$ & $7.6 a$ \\
\hline T5 & $37.4 \mathrm{a}$ & $453 a$ & $54.4 \mathrm{a}$ & $52.6 \mathrm{a}$ & $2.8 \mathrm{a}$ & $6.4 \mathrm{a}$ & $2.0 \mathrm{a}$ & $7.7 \mathrm{a}$ \\
\hline Average & 35.8 & 449 & 55.7 & 50.8 & 2.8 & 6.4 & 2.0 & 7.6 \\
\hline LSD & 8.4 & 101.7 & 9.4 & 3.5 & 0.3 & 0.3 & 0.1 & 0.7 \\
\hline C.V. & 23.9 & 22.2 & 8.9 & 3.7 & 6.0 & 2.4 & 2.4 & 4.8 \\
\hline
\end{tabular}

* Means in each column followed by the same letter do not differ statistically at the 0.05 level by Tukey Test; C.V. - variation coefficient; LSD - Least Significant Difference.

The second year yield shows similar results to the first year yield. Irrigated treatments had $30 \%$ to $40 \%$ more yield than non irrigated trees. The yield in T2, T3, T4, and T5 differed 
significantly $(P<0.05)$ from T1. There was no significant difference among the different irrigation levels.

The results indicate the necessity of scheduling irrigations, because the lime crop did not increase yield proportionally to irrigation levels. Probably, due water stress was lower in second harvest year (Figure 3). Irrigating with at least $25 \%$ of ETc could significantly increase yield. Trees irrigated at $25 \%$ and $100 \%$ of ETC (3 years old) gave yields that were $86 \%$ and $122 \%$ higher than non irrigated trees, respectively.

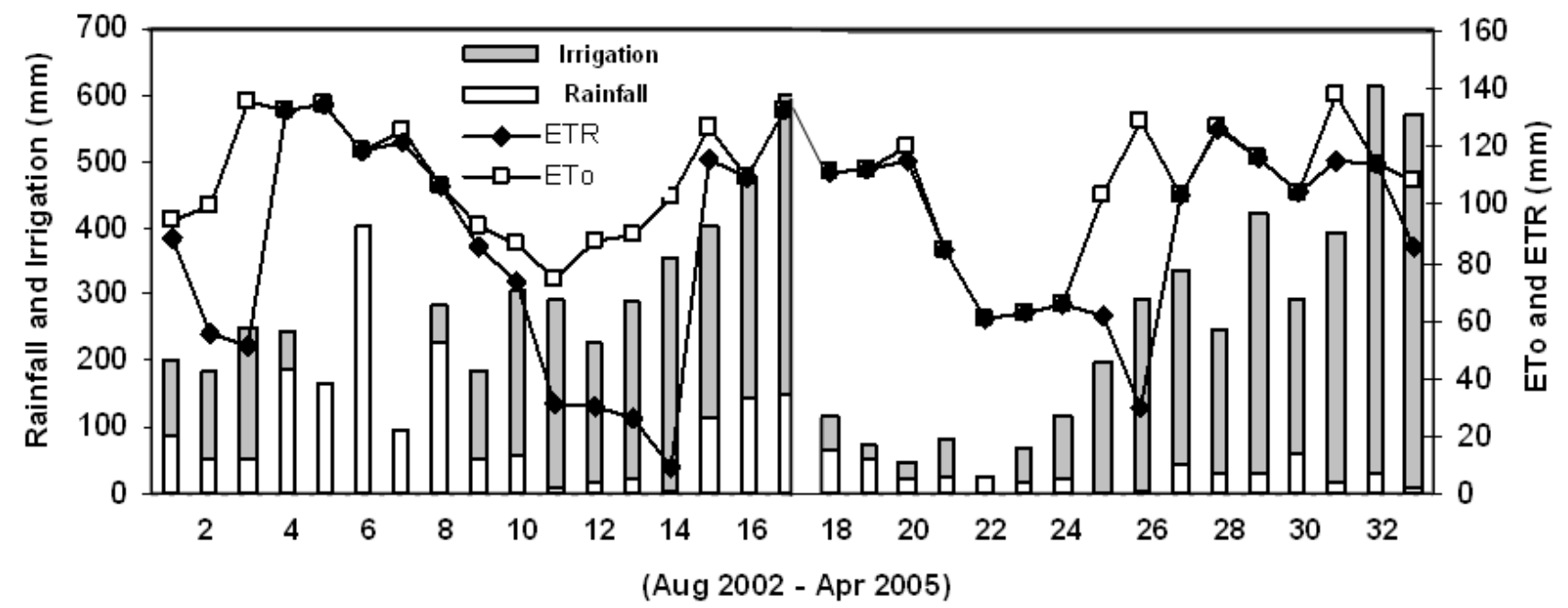

FIGURE 3. Rainfall, irrigation, reference (ETo) and real evapotranspiration (ETR) during experimental time (August of 2002 to September of 2003) in Piracicaba - SP, Brazil.

These results are in according to CASTEL (1994) and SOUZA et al. (2003), who showed that irrigation can increase annual yield of citrus. GAYET et al. (1995) observed that acid lime starts to produce an economical yield when the tree is 3 years old. This study showed that irrigation contributed to earlier yield. Three-year-old irrigated trees produced like 5-year-old trees that are not irrigated, as related by COELHO (1993). He showed that in São Paulo, yield of lime depends on tree age, e.g. 8 to $15 \mathrm{~kg}$ per tree at 3 years old, 23 to $37 \mathrm{~kg}$ per tree at 4 years old, 64 to $86 \mathrm{~kg}$ per tree at 5 years old, and 68 to $141 \mathrm{~kg}$ at 6 years old.

With the second year yield (4 years old), trees irrigated with $25 \%$ of ETc $\left(39.9 \mathrm{~kg} \mathrm{tree}^{-1}\right)$ showed $40 \%$ higher productivity than non irrigated trees $\left(28.3 \mathrm{~kg}\right.$ tree $\left.^{-1}\right)$. Irrigated trees at 4 years old produced like 4-year-old trees that are not irrigated (COELHO, 1993). This was probably due the characteristic al ternate cropping (biennial bearing) of citrus, as related by FORSYTH (2003).

Table 2 also shows that there was no significant difference $(P<0.05)$ among irrigation levels and fruit quality, such as percent of juice, total soluble solid (TSS), pH, total acidity, rind thickness, and fruit diameter. Similar results were obtained by SILVA et al. (2007) in the same experimental area. DOMINGOS et al. (1996) did not verified effect of irrigation on chemical characteristics of Fruits in lemon trees. GINESTAR \& CASTEL (1996) observed the effect of water stress on TSS was different in each year of the experiment and presumably be attributed to the differences in air temperature.

Normally, acidity is an important commercialization factor for 'Tahiti' acid lime. Average total acidity found in this study was considered acceptable, being between of the interval of $6 \%$ to $8 \%$ in accordance with GAYET et al. (1995). The results of total soluble solids obtained in this study are between 7 and $8^{\circ}$ Brix, which was very similar results obtained by SILVA et al. (2007) and SOUZA et al., (2003) to same variety. 
TABLE 3. Amount of used water for irrigation of the 'Tahiti' acid lime trees in the treatments (Irrigation levels $100 \%, 75 \%, 50 \%$ and $25 \%$ of ETc).

\begin{tabular}{|c|c|c|c|c|c|}
\hline \multirow{2}{*}{ Month } & \multirow{2}{*}{ Month/year } & \multicolumn{4}{|c|}{ Irrigatio (liters tree ${ }^{-1}$ day $^{-1}$ ) } \\
\hline & & $100 \%$ ETc & $75 \%$ ETc & $50 \%$ ETc & $25 \%$ ETc \\
\hline 1 & Aug/2002 & 4.10 & 3.08 & 2.05 & 1.03 \\
\hline 2 & $\mathrm{Sep} / 2002$ & 4.80 & 3.60 & 2.40 & 1.20 \\
\hline 3 & Oct/2002 & 7.28 & 5.46 & 3.64 & 1.82 \\
\hline 4 & Nov/2002 & 2.13 & 1.60 & 1.07 & 0.53 \\
\hline 5 & Dec/2002 & 0.00 & 0.00 & 0.00 & 0.00 \\
\hline 6 & Jan/2003 & 0.00 & 0.00 & 0.00 & 0.00 \\
\hline 7 & $\mathrm{Feb} / 2003$ & 0.00 & 0.00 & 0.00 & 0.00 \\
\hline 8 & Mar/2003 & 2.06 & 1.55 & 1.03 & 0.52 \\
\hline 9 & Apr/2003 & 4.91 & 3.68 & 2.46 & 1.23 \\
\hline 10 & Mai/2003 & 9.08 & 6.81 & 4.54 & 2.27 \\
\hline 11 & Jun/2003 & 10.74 & 8.06 & 5.37 & 2.69 \\
\hline 12 & $\mathrm{Jul} / 2003$ & 7.61 & 5.71 & 3.81 & 1.90 \\
\hline 13 & Aug/2003 & 9.84 & 7.38 & 4.92 & 2.46 \\
\hline 14 & $\mathrm{Sep} / 2003$ & 13.06 & 9.80 & 6.53 & 3.27 \\
\hline 15 & Oct/2003 & 10.49 & 7.87 & 5.25 & 2.62 \\
\hline 16 & Nov/2003 & 12.41 & 9.31 & 6.21 & 3.10 \\
\hline 17 & Dec/2003 & 16.40 & 12.30 & 8.20 & 4.10 \\
\hline 18 & Jan/2004 & 7.62 & 5.71 & 3.81 & 1.90 \\
\hline 19 & $\mathrm{Feb} / 2004$ & 3.05 & 2.29 & 1.53 & 0.76 \\
\hline 20 & Mar/2004 & 3.70 & 2.78 & 1.85 & 0.93 \\
\hline 21 & Apr/2004 & 8.20 & 6.15 & 4.10 & 2.05 \\
\hline 22 & Mai/2004 & 0.00 & 0.00 & 0.00 & 0.00 \\
\hline 23 & Jun/2004 & 7.41 & 5.55 & 3.70 & 1.85 \\
\hline 24 & $\mathrm{Jul} / 2004$ & 14.18 & 10.63 & 7.09 & 3.54 \\
\hline 25 & Aug/2004 & 28.89 & 21.66 & 14.44 & 7.22 \\
\hline 26 & Sep/2004 & 44.42 & 33.31 & 22.21 & 11.10 \\
\hline 27 & Oct/2004 & 42.85 & 32.14 & 21.43 & 10.71 \\
\hline 28 & Nov/2004 & 32.83 & 24.62 & 16.41 & 8.21 \\
\hline 29 & Dec/2004 & 57.77 & 43.33 & 28.89 & 14.44 \\
\hline 30 & $\mathrm{Jan} / 2005$ & 34.65 & 25.99 & 17.33 & 8.66 \\
\hline 31 & $\mathrm{Feb} / 2005$ & 61.17 & 45.88 & 30.59 & 15.29 \\
\hline 32 & Mar/2005 & 85.70 & 64.28 & 42.85 & 21.43 \\
\hline 33 & Apr/2005 & 85.28 & 63.96 & 42.64 & 21.32 \\
\hline
\end{tabular}

Using the Brazilian classification system (HORTBRASIL, 2000), the fruits are classified as Group ' $A$ ' when percent juice is between $30 \%$ to $35 \%$, group ' $B$ ' $42 \%$ to $50 \%$, and group ' $C$ ' above $55 \%$. Therefore, the average percent juice in this study can be put into the category $\mathrm{B}$ and $\mathrm{C}$ in the first $(41.7 \%)$ and second $(55.7 \%)$ year of yield, respectively.

Fruits are also ideal to harvest when they are between 47 to $65 \mathrm{~mm}$ of diameter (GAYET et al., 1995). Using the Brazilian classification system (HORTBRASIL, 2000), the fruits were classified as Class 50 with diameters between 50 to $53 \mathrm{~mm}$.

\section{CONCLUSION}

Young trees irrigated with $100 \%$ of crop evapotranspiration resulted in greater growth of 'Tahiti' acid lime in field conditions.

With trees that were 33 months old, irrigation did not influence root distribution in depth. However, irrigation influenced root distribution horizontally. Trees irrigated at $75 \%$ and $100 \%$ of crop evapotranspiration showed horizontal root distribution concentrated between 0.0 to $0.6 \mathrm{~m}$ from the trunk. 
With 48-month-old trees, irrigation had no effect on root distribution in the soil profile, and the effective $(80 \%)$ rooting distribution were located to $0.6 \mathrm{~m}$ of depth and $0.6 \mathrm{~m}$ horizontally.

Irrigation with $25 \%$ of crop evapotranspiration induced earlier yield, and increased yield and number of fruits per tree.

Irrigation did not improve the quality of fruit.

\section{REFERENCES}

AGRIANUAL 2007. Anuário da agricultura brasileira. São Paulo: FNP Consultoria \& Comércio, 2007. $516 \mathrm{p}$.

ALVES JÚNIOR, J.; SILVA, C.R.; SILVA, T.J.A.; RIBEIRO, R.V.; FOLEGATTI, M.V. Crescimento de plantas jovens de limeira-ácida 'Tahiti' sob lâminas de irrigação. Engenharia Agrícola, Jaboticabal, v.25, n.1, p.170-178, jan./abr. 2005.

ALVES JÚNIOR, J. Necessidade hídrica e resposta da cultura de lima-ácida 'Tahiti' a diferentes níveis de irrigação. 2006. 100 f. Tese (Doutorado em Irrigação e Drenagem) - Escola Superior de Agricultura "Luiz de Queiroz", Universidade de São Paulo, Piracicaba, 2006.

BARBOSA JR., C.R.A.; FOLEGATTI, M.V.; ROCHA, F.J.; ATARASSI, R.T. Coeficiente de cultura de lima-ácida 'Tahiti' no outono-inverno determinado por lisimetria de pesagem em Piracicaba-SP. Engenharia Agrícola, Jaboticabal, v.28, n.4, p.691-698, out./dez. 2008.

BOLLER, E.F.; AVILLA, J.; JÖRG, E.; MALAVOLTA, C. WIJNANDS, F.;ESBJERG, P. Integrated production: principles and technical guidelines. IOBC/WPRS Bulletin, v.27, n.2, 2004. Disponível em <http://www.iobc.ch/download_docs.html>. Acesso em: 01 jul. 2008.

BOHM, W. Methods of studying root systems. Heidelberg: Berlin: Springer-Verlag, 1979. 189 p. (Ecologcal Studes, 330).

BUSTAN, A.; GOLDSCHMIDT, E.E. Estimating the cost of flowering in a grapefruit tree. Plant Cell Environment, Oxford, v.21, p.217-224, 1998.

CASTEL, J.R. Response of young clementine citrus trees to drip irrigation. I. Irrigation amount and number of drippers. Journal of Horticultural Science, Ashford, v.69, n.3, p.481-489, 1994.

CASTEL, J.R. Response of young clementine citrus trees to drip irrigation. Acta Horticulturae, Wageningen, v.335, p.313-324, 1993.

CASTLE, W.S.; TUCKER, D.P.H.; KREZDORN, A.H.; YOUTSEY, C.O. Rootstocks for Florida citrus; rootstock selection, the first step to success. $2^{\text {nd }}$ ed. Gainesville: University of Florida, 1993. $92 \mathrm{p}$.

COELHO, Y.S. Lima-ácida 'Tahiti': aspectos da produção. Brasília: EMBRAPA, 1997. 35 p. (Série Didática FRUPEX, 1).

COELHO, E.F.; OLIVEIRA, F.C.; ARAÚJO, E.C.E.; VASCONCELOS, L.F.L. Distribuição de raízes de laranja 'Pera' sob sequeiro e irrigação por microaspersão em solo arenoso. Pesquisa Agropecuária Brasileira, Brasília, v.37, n.5, p.603-611, 2002.

DAVIES, F.S.; ALBRIGO, L.G. Cítrus. Wallingford: CAB International, 1994. 254 p.

DOMINGO, R.; RUIZ-SÁNCHEZ, M.C.; SÁNCHEZ-BLANCO, M.J.; TORRECILLAS, A. Water relations, growth and yield of fino lemon trees under regulated deficit irrigation. Irrigation Science, Berlin, v.16, p.115-123, 1996.

FORSYTH, J. Citrus in the garden. $4^{\text {th }}$ ed. 2003. Disponível em <http://www.agric.nsw.gov.au/reader/gr-varieties/h217.htm\#Limes>. Acesso em: 15 out. 2007. 
GAYET, J.P.; BLEINROTH, E.W.; MATALLO, M.; GARCIA, E.E.C.; GARCIA, A.E.; ARDITO, E.F.G.; BORDIN, M.R. Lima-ácida 'Tahiti' para exportação: procedimentos de colheita e póscolheita. Brasília: MAARA/SDR. 1995. 36 p. (Série Publicações Técnicas FRUPEX, 12).

GINESTAR, C.; CASTEL, J.R. Responses of Young clementine citrus trees to water stress during different phenological periods. Journal of Horticultural Science, Ashford, v.71, n.4, p.551-559, 1996.

\section{HORTIBRASIL. INSTITUTO BRASILEIRO PARA QUALIDADE NA AGRICULTURA.} Programa brasileiro para melhoria dos padrões comerciais e embalagens de hortigranjeiros: classificação do limão (lima ácida) Tahiti (Citrus latifolia Tanaka). São Paulo: CEAGESP, 2000. $5 \mathrm{p}$.

MATTOS JR., D.; GRAETZ, D.A.; ALVA, A.K. Biomass distribution and nitrogen-15 partitioning in citrus trees on a sandy entisol. Soil Science Society of America Journal, Ashford, v.67, p.555$563,2003$.

MORGAN, K.T.; OBREZA, T.A.; SCHOLBERG, J.M.S.; PARSONS, L.R. WHEATON, T.A. Citrus water uptake dynamics on a sandy Florida Entisol. Soil Science Society of America Journal, Ashford, v.70, p.90-97, 2006.

PARSONS, L.R.; MORGAN, K.T.; WHEATON, T.A.; CASTLE, W.S. High application rates of reclaimed water benefit citrus tree growth and fruit production. HortScience, Alexandria, v.36, p.1.273-1.277, 2001.

PARSONS, L.R. Weather and irrigation for the new year. Citrus Industry, Barton, v.86, n.1, p.1617, 2005.

RAIJ, B.van; SILVA, N.M.; BATAGLIA, O.C.; QUAGGIO, J.A.; HIROCE, R.; CANTARELLA, H.; BELLINAZZI, J.R.; DECHEN, A.R.; TRANI, P.E. Recomendações de adubação e calagem para o Estado de São Paulo. Campinas: Instituto Agronômico, 2000. (Boletim Técnico 100 versão disponível em: <http://www.iac.sp.gov.br>).

SANTANA, M.B.; SOUZA L.S.; SOUZA, L.D.; FONTES, L.E.F. Soil physical attributes and citrus root system distribution as indicators of cohesive layers in soils of coastal tablelands in the State of Bahia, Brazil. Revista Brasileira de Ciência do Solo, Viçosa-MG, v.30, n.1, p.1-12, 2006.

SANTOS, D.B. dos; COELHO, E.F.; AZEVEDO, C.A.V. de. Absorção de água pelas raízes do limoeiro sob distintas frequências de irrigação. Revista Brasileira de Engenharia Agrícola Ambiental, Campina Grande, v.9, n.3, p.327-333, 2005.

SILVA, C.R. da; ROCHA, F.J.; ALVES JÚNIOR, J.; SILVA, T.J.A. da; FOLEGATTI, M.V.; MASCHIO, R. Respostas de limeira-ácida 'Tahiti' à suspensão da irrigação em diferentes períodos fenológicos. Laranja, Cordeirópolis, v.27, p.321-339, 2007.

SOUZA, L.D.; CUNHA SOBRINHO, A.P.; RIBEIRO, L.S.; SOUZA, L.S.; LEDO, C.A.S. Avaliação de plantas cítricas, em diferentes profundidades de plantio, em Latossolo Amarelo dos Tabuleiros Costeiros. Revista Brasileira de Fruticultura, Jaboticabal, v.26, p.241-244, 2004.

SOUZA, M.J.H.; RAMOS, M.M.; SIQUEIRA, D.L.; COSTA, L.C.; LHAMAS, A.J.M.; MANTOVANI, E.C.; CECON, P.R.; SALOMÃO, L.C.C. Produção e qualidade dos frutos da limeira-ácida 'Tahiti' submetida a diferentes porcentagens de área molhada. Revista Brasileira de Engenharia Agrícola e Ambiental, Campina Grande, v.7, n.2, p.245-250, 2003.

TESTEZLAF, R.; COLETTI, C.; MATSURA, E.E. Distribuição de raízes da laranja 'Valência' irrigada por autopropelido. Pesquisa Agropecuária Brasileira, Brasília, v.42, p.905-908, 2007.

USDA. Foreign Agriculture Service. 2005. Brazil Citrus. Annual Report 2005. Gain report BR5026. Global Agriculture Information Network. Disponível em <http://www.fas.usda.gov/gainfiles/200512/146131807.doc>. Acesso em: 15 jul. 2007. 
WHEATON, T.A.; CASTLE, W.S.; WHITNEY, J.D.; TUCKER, D.P. Performance of citrus scion cultivars and rootstocks in a high density planting. HortScience, Alexandria,v.26, p.837-840,1991.

WRIGHT, G.C. Irrigating citrus trees. Cooperative Extension. University of Arizona. College of Agriculture. AZ1151, 2000. 5p. Disponível em: <cals.arizona.edu/pubs/crops/az1151.pdf>. Acesso em: 20 mar. 2007. 